\title{
The Impact of Operational Efficiency on the Future Performance of Indian Manufacturing Firms
}

\author{
Amarjit Gill ${ }^{1}$, Manjeet Singh ${ }^{2}$, Neil Mathur ${ }^{3} \&$ Harvinder S. Mand ${ }^{4}$ \\ ${ }^{1}$ Department of Finance and Management Science, Edwards School of Business, University of Saskatchewan, \\ Canada \\ ${ }^{2}$ Punjabi University, Patiala, Punjab, India \\ ${ }^{3}$ College of Management \& Technology Walden University, Minneapolis, USA \\ ${ }^{4}$ University College, Ghudda (Bathinda), East Punjab, India \\ Correspondence: Amarjit Gill, The University of Saskatchewan, Edwards School of Business, Department of \\ Finance and Management Science, 25 Campus Drive, Saskatoon, SK, S7N-5A7, Canada. Tel: 1-306-966-2547. \\ E-mail: gill@edwards.usask.ca
}

Received: July 22, 2014

doi:10.5539/ijef.v6n10p259
Accepted: July 30, 2014

Online Published: September 25, 2014

\begin{abstract}
This study investigated the relationship between changes in operational efficiency and changes in future performance of Indian manufacturing firms applying a correlational research design. A sample of 244 firms was selected from the top 500 companies listed on the Bombay Stock Exchange (BSE) for a period of five years (from 2008-2012). The findings of this study indicate that changes in operational efficiency play a role in the future performance of Indian manufacturing firms. This study contributes to the literature on the factors that cause changes in firms' future performance. The findings may be useful for financial managers, operations managers, investors, financial management consultants, and other stakeholders.
\end{abstract}

Keywords: operational efficiency, future firm performance, financial performance, share prices

\section{Introduction}

One of the most important goals of a corporation's leadership is to maximize the present and future financial and operational performance because they impact the market price per share and consequently, shareholders' wealth. Common business practice implies that operational efficiency (OE) plays an important role in improving current and future firm performance. In the context of this study, Operational Efficiency is defined as the extent to which changes in the cash conversion cycle, operating expenses to sales revenue ratio, operating cash flow, total asset turnover, total debt to total assets ratio, firm size, and operating risk impact the future performance of the firm. The term 'efficiency' is viewed in both the industrial organization and strategic management literature as the product of firm-specific factors such as management skills, innovation, cost control, and market share as determinants of current firm performance and its stability (Abuzayed \& Molyneux, 2009; McWilliams \& Smart, 1993). Although the concept of efficiency has been used widely for bank valuation, it has not been used greatly in valuation studies related to other private industry firms. The present study was conducted using accounting measures to investigate the impact of changes in $\mathrm{OE}$ on changes in future firm performance. We explore the following research question:

\section{Do the changes in operational efficiency impact the future performance of Indian manufacturing firms?}

In order to survive and prosper, firms have to produce their output from input efficiently. Producing more output from unchanged input, consuming less input for unchanged output, reducing operating costs without damaging the corporation, reducing the days in the cash conversion cycle, improving operating cash flows, increasing total asset turnover, and effecting reductions in operating risk are all signs of relative operational efficiency. Therefore, OE can be used as a proxy for competitive advantage, which affects the firm's current profitability and its future potential performance.

In this study, we concentrate on future firm performance. According to McWilliams and Smart (1993), firms that operate efficiently can exploit their competitive advantage and produce sustainable profits for a longer period, 
thereby establishing a sustainable competitive advantage.

Previous authors (Abarbanell \& Bushee, 1997; Baik, Chae, Choi, \& Farber, 2010; Fairfield \& Yohn, 2001; Lev \& Thiagarajan, 1993; Nissim \& Penman, 2001; Ou \& Penman, 1989; Penman \& Zhang, 2002) studied the impact of $\mathrm{OE}$ ratios on future firm performance. In Section 2, we briefly review previous authors' findings.

The present study is one of the few studies that explicitly evaluate the relationship between OE of the firm and future firm performance for emerging market firms. The importance of this study also lies in the use of financial ratios, a method which can be useful for financial analysis. The ratios used in this study can be applied in future research on performance measurement systems and the results can be used for teaching financial ratios and financial analysis. The paper provides insight for policy-makers as to the importance of $\mathrm{OE}$ in influencing shareholder wealth maximization in Indian Top 500 Firms. The findings reported in this study indicate the importance of $\mathrm{OE}$ in improving future firm performance. Thus, this study adds empirical substance to existing theory.

\section{Relevant Literature Review}

The importance of $\mathrm{OE}$ in improving future firm performance cannot be ignored. For-profit corporations exist to make a profit. Indeed, researchers used accounting ratios to measure the $\mathrm{OE}$ of the firm and to test the relationship between $\mathrm{OE}$ and future firm performance in several countries. The following is a brief literature review on the relationship between $\mathrm{OE}$ and firm performance.

Ou and Penman (1989), sampling U.S. firms for the period 1973-1983 and using financial statement ratios, found that financial ratios predict earnings changes one year in advance.

Using a sample of U.S. firms for the period 1974-1988, Lev and Thiagarajan (1993) identified a set of 12 fundamental accounting signals used in Value Line analyst reports, such as receivables growth and inventory growth, and examined the predictive power of these signals for current returns.

Abarbanell and Bushee (1997), by extending the model of Lev and Thiagarajan (1993), found that fundamental signals have predictive power for future earnings changes.

Fairfield and Yohn (2001), sampling 9,147 U.S. firms for the years 1977-1996 and decomposing changes in return on net operating assets into changes in profit margin and changes in asset turnover, found that only changes in asset turnover are useful for predicting future profitability changes.

Using U.S. data for the period 1963-1999, Nissim and Penman (2001) found that changes in asset turnover are related to current and future earnings changes.

Penman and Zhang (2002), using 46,854 observations from U.S. firms for the period 1975-1997, studied research and development (R\&D) expenses as a "hidden reserve" and found that they lead to positive future stock returns.

Using a sample of 94 Pakistani firms listed on the Karachi Stock Exchange for a period 1999-2004, Raheman and Nasr (2007) found that as the cash conversion cycle increases, it leads to decreasing profitability of the firm.

Falope and Ajilore (2009), using a sample of 50 Nigerian quoted non-financial firms for the period 1996-2005, found a significant negative relationship between net operating profitability and the cash conversion cycle.

Baik, Chae, Choi, and Farber (2010) used 72,303 US firm-year observations for the period 1976-2007, and showed that efficiency changes predict future firm performance.

Ahmad and Noor (2010), using 78 Islamic banks in 25 countries for the period 1992-2009, found a positive relationship between operating efficiency and profitability.

Dietrich (2010) examined the impact of efficiency on profitability using a panel of 11,728 UK manufacturing firms for the period 1993-2007, and found that operating efficiency above the threshold positively impacts profitability in the short-run.

Rahman and Farah (2012) investigated the indicators of profitability in the non-banking financial institutions (NBFIs) industry of Bangladesh and found that operating efficiency improves profitability.

Table 1 summarizes the findings of these studies. 
Table 1. Previous findings on the relationship between operational efficiency and future firm performance

\begin{tabular}{ll}
\hline Author(s) & Previous Findings \\
& Found that: \\
\hline Ou and Penman (1989) & Financial ratios predict the sign of one-year-ahead earnings changes. \\
Fairfield and Yohn (2001) & Changes in asset turnover predict future profitability changes. \\
Nissim and Penman (2001) & Changes in research and development expenses predict future performance. \\
Penman and Zhang (2002) & As the cash conversion cycle increases, it leads to decreasing profitability of \\
Raheman and Nasr (2007) & Pakistan increase in cash conversion cycle decreases operating profitability. \\
Falope and Ajilore (2009) & OPficiency changes predict future firm performance. \\
Baik, Chae, Choi, and Farber (2010) & Operating efficiency positively impacts profitability in the short-run. \\
Ahmad and Noor (2010) & Operating efficiency improves the profitability. \\
$\begin{array}{l}\text { Dietrich (2010) } \\
\text { Rahman and Farah (2012) }\end{array}$ &
\end{tabular}

In summary, the theoretical foundation of this study is that current operational efficiency (measured by cash conversion cycle, operating expenses, operating cash flow, and asset turnover) impacts the future performance of the firm. The impact of operational efficiency on future performance of the firm can be positive or negative. Hence, the following hypotheses are formulated:

H1: The changes in cash conversion cycle impact the future performance of the firm.

H2: The changes in operating expenses impact the future performance of the firm.

H3: The changes in operating cash flow impact the future performance of the firm.

H4: The changes in asset turnover impact the future performance of the firm.

\section{Method}

To conduct this study, we applied correlational and non-experimental research design. There is no single measure that fully expresses operational efficiency of the firm. Therefore, four different component measures of operational efficiency were used (see Table 2).

\subsection{Measurement}

To remain consistent with previous studies, we adopted measures used in previous studies.

i) Ratios related to the Cash Conversion Cycle and measures for Firm Size were taken from Gill and Biger (2013). The cash conversion cycle is an important aspect of corporate efficiency as it impacts the future performance of the firm. For example, if the cash conversion cycle of a production firm increases, the firm will face cash flow problems. Cash flow problems may lead to financial distress.

ii) Firm size shows the level of company operations and the level of assets. The change in firm size from small to large impacts the OE of the firm.

iii) Ratios related to Operating Expenses to Sales Revenue were taken from Ohlson and Penman (1992). Current changes in overall operating expenses impact the $\mathrm{OE}$ as well as future firm performance.

iv) Ratios related to Total Debt to Total Assets came from Hossan and Habib (2010). The ratio of total debt to total assets measures a company's financial leverage. The higher level of company leverage increases the risk of financial distress which in turn increases the chances of bankruptcy. Thus, the change in total debt to total assets ratio impacts present and future firm performance.

v) Ratios related to Total Asset Turnover were taken from Homsud and Choksuchat (2012). Asset turnover measures the efficiency of a company's use of its assets in generating sales revenue, which is important for present and future firm performance.

vi) Measures related to Operating Cash Flow came from Gill, Biger, and Tibrewala (2010). Operating cash flow measures the efficiency of cash conversion cycle.

vii) Future Firm Performance (measured by changes in market value of company shares) was taken from Sharma and Singh (2006). Change in market value of company share measurement was used as the dependent variable to measure future firm performance because return on equity and return on assets measurements are affected by non-efficiency issues such as product pricing challenges because of the changes in market competition, shortage 
of raw material, etc.

Table 2 provides more details on the measurements of the dependent, independent, and control variables that were used in regression analysis.

Table 2. Proxy variables and their measurements

\begin{tabular}{|c|c|}
\hline Dependent Variables & Measurement \\
\hline Future Performance $\left(\Delta \mathrm{FP}_{\mathrm{i}, \mathrm{t}}\right)$ & (Highest market value per share + Lowest market value per shares) $/ 2$ \\
\hline Independent Variables & Measurement \\
\hline Cash Conversion Cycle $\left(\Delta \mathrm{CCC}_{\mathrm{i}, \mathrm{t}}\right)$ & (No. of days A/R + No. of days inventory) - No. of days A/P \\
\hline Operating Expenses to Sales Revenue Ratio $\left(\Delta \mathrm{OE} \_\mathrm{SR}_{\mathrm{i}, \mathrm{t}}\right)$ & Operating expenses / Sales revenue \\
\hline Total Asset Turnover $\left(\Delta \mathrm{TAT}_{\mathrm{i}, \mathrm{t}}\right)$ & Sales / Total assets \\
\hline \multicolumn{2}{|l|}{ Control Variable } \\
\hline Total Debt to Total Assets Ratio $\left(\Delta \mathrm{TDTA}_{\mathrm{i}, \mathrm{t}}\right)$ & Total debt / Total assets \\
\hline Firm Size $\left(\Delta \mathrm{FS}_{\mathrm{i}, \mathrm{t}}\right)$ & Log of average assets \\
\hline $\operatorname{Risk}\left(\Delta \mathrm{SD}_{\mathrm{i}, \mathrm{t}}\right)$ & Change in SD over previous year \\
\hline
\end{tabular}

Note. $\mu_{\mathrm{i}, \mathrm{t}}=$ the error term; Change $(\Delta)=($ Current year - Previous year $) /$ Previous year; $\mathrm{SD}=$ Standard deviation.

The regression models of this study is as follows:

$$
\begin{aligned}
& \Delta F P=\alpha+\beta_{1} \Delta C C C_{i, t}+\beta_{2} \Delta T D T A_{i, t}+\beta_{3} \Delta F S_{i, t}+\beta_{4} \Delta S D_{i, t}+\mu_{i t} \\
& \Delta F P=\alpha+\beta_{1} \Delta O E_{-} S R_{i, t}+\beta_{2} \Delta T D T A_{i, t}+\beta_{3} \Delta F S_{i, t}+\beta_{4} \Delta S D_{i, t}+\mu_{i t} \\
& \Delta F P=\alpha+\beta_{1} \Delta O C F_{i, t}+\beta_{2} \Delta T D T A_{i, t}+\beta_{3} \Delta F S_{i, t}+\beta_{4} \Delta S D_{i, t}+\mu_{i t} \\
& \Delta F P=\alpha+\beta_{1} \Delta T A T_{i, t}+\beta_{2} \Delta T D T A_{i, t}+\beta_{3} \Delta F S_{i, t}+\beta_{4} \Delta S D_{i, t}+\mu_{i t}
\end{aligned}
$$

\subsection{Data Collection}

A database was built from a sample of approximately 500 financial reports from publicly traded companies between January 1, 2008 and December 31, 2012. The sample was drawn from the Bombay Stock Exchange (BSE) Top 500 Companies (www.prowess.cmie.com) to collect a sample of manufacturing firms. The purpose of selecting Top 500 Companies was to understand how financially strong companies' efficiency impacts their future performance because investors prefer to invest in these companies. Out of approximately 500 financial reports announced by public companies between January 1, 2008 and December 31, 2012, only 244 financial reports were usable. The cross sectional yearly data were used in this study. Thus, 244 financial reports resulted in 1,220 total observations.

The sample excludes companies from the service industry. In addition, some of the firms were not included in the data due to lack of information for the periods being studied.

\subsection{Descriptive Statistics}

Table 3 shows descriptive statistics of the collected variables. The explanation of changes in each variable is described as follows:

i) $\triangle \mathrm{FP}($ Changes in share price $)=2010:-43.60 \% ; 2011:-2.40 \% ; 2012:-9.10 \%$;

ii) $\triangle \mathrm{CCC}($ Cash conversion cycle $)=2009: 18.90 \% ; 2010:-1.50 \% ; 2011: 2.90 \%$;

iii) $\triangle$ OE_SR (Changes in operating expenses to sales revenue ratio) $=2009: 6.20 \% ; 2010:-3.80 \% ; 2011: 3.50 \%$;

iv) $\triangle \mathrm{OCF}$ (Changes in operating cash flow) $=2009:-5.20 \% ; 2010: 13.50 \% ; 2011:-31.60 \%$;

v) $\triangle \mathrm{TAT}$ (Changes in total asset turnover) $=2009: 0.90 \% ; 2010:-2.60 \% ; 2011:-0.30 \%$;

vi) $\triangle$ TDTA (Changes in total debt to total assets ratio) $=2009: 19.70 \% ; 2010:-2.20 \% ; 2011: 0.10 \%$;

vii) $\triangle \mathrm{FS}$ (Changes in firm size $)=2009: 2.10 \% ; 2010: 1.60 \% ; 2011: 1.90 \%$;

viii) $\Delta$ SD (Changes in standard deviation - operating risk $)=2009: 2.45 \% ; 2010: 2.57 \% ; 2011: 1.99 \%$. 
Table 3. Descriptive statistics

\begin{tabular}{|c|c|c|c|c|}
\hline \multicolumn{5}{|c|}{$\Delta \mathrm{OE}$ From 2008 to 2009 and $\Delta \mathrm{FP}$ From 2009 to $2010\left(\Delta \mathrm{FP}_{10}\right)$} \\
\hline & Minimum & Maximum & Mean & $\mathrm{SD}$ \\
\hline$\Delta \mathrm{FP}_{10}$ & -0.95 & 0.92 & -0.436 & 0.327 \\
\hline$\Delta \mathrm{CCC}_{09}$ & -5.61 & 7.41 & 0.189 & 1.708 \\
\hline$\Delta \mathrm{OE} \_\mathrm{SR}_{09}$ & -0.81 & 0.96 & 0.062 & 0.174 \\
\hline$\triangle \mathrm{OCF}_{09}$ & -7.80 & 5.16 & -0.052 & 1.653 \\
\hline$\Delta \mathrm{TAT}_{09}$ & -0.62 & 0.99 & 0.009 & 0.247 \\
\hline$\Delta \mathrm{TDTA}_{09}$ & -0.61 & 0.95 & 0.197 & 0.253 \\
\hline$\Delta \mathrm{FS}_{09}$ & -0.07 & 0.68 & 0.021 & 0.047 \\
\hline$\Delta \mathrm{SD}_{09}$ & 0.01 & 19.18 & 2.445 & 3.523 \\
\hline \multicolumn{5}{|c|}{$\Delta \mathrm{OE}$ From 2009 to 2010 and $\Delta \mathrm{FP}$ From 2010 to $2011\left(\Delta \mathrm{FP}_{11}\right)$} \\
\hline & Minimum & Maximum & Mean & SD \\
\hline$\Delta \mathrm{FP}_{11}$ & -0.97 & 0.99 & -0.024 & 0.408 \\
\hline$\Delta \mathrm{CCC}_{10}$ & -5.90 & 6.20 & -0.015 & 1.278 \\
\hline$\Delta \mathrm{OE} \_\mathrm{SR}_{10}$ & -0.39 & 0.99 & -0.038 & 0.125 \\
\hline$\Delta \mathrm{OCF}_{10}$ & -8.98 & 9.43 & 0.135 & 1.833 \\
\hline$\Delta \mathrm{TAT}_{10}$ & -0.52 & 0.81 & -0.026 & 0.193 \\
\hline$\Delta \mathrm{TDTA}_{10}$ & -0.52 & 0.99 & -0.022 & 0.188 \\
\hline$\Delta \mathrm{FS}_{10}$ & -0.05 & 0.15 & 0.016 & 0.188 \\
\hline$\Delta \mathrm{SD}_{10}$ & 0.01 & 18.88 & 2.572 & 3.692 \\
\hline \multicolumn{5}{|c|}{$\Delta \mathrm{OE}$ From 2010 to 2011 and $\Delta \mathrm{FP}$ From 2011 to $2012\left(\Delta \mathrm{FP}_{12}\right)$} \\
\hline & Minimum & Maximum & Mean & SD \\
\hline$\Delta \mathrm{FP}_{12}$ & -0.99 & 0.98 & -0.091 & 0.371 \\
\hline$\Delta \mathrm{CCC}_{11}$ & -5.59 & 5.29 & 0.029 & 1.196 \\
\hline$\Delta \mathrm{OE} \_\mathrm{SR}_{11}$ & -0.84 & 0.83 & 0.035 & 0.135 \\
\hline$\Delta \mathrm{OCF}_{11}$ & -8.78 & 9.78 & -0.316 & 1.745 \\
\hline$\Delta \mathrm{TAT}_{11}$ & -1.98 & 1.10 & -0.003 & 0.258 \\
\hline$\Delta \mathrm{TDTA}_{11}$ & -0.94 & 0.86 & 0.001 & 0.180 \\
\hline$\Delta \mathrm{FS}_{11}$ & -0.02 & 0.33 & 0.019 & 0.025 \\
\hline$\Delta \mathrm{SD}_{11}$ & 0.00 & 18.76 & 1.997 & 3.175 \\
\hline
\end{tabular}

Note. $\mathrm{SD}=$ Standard deviation; $\mathrm{FP}=$ Future firm performance measured as changes in market value of company share; $\Delta \mathrm{OE}=\mathrm{Change}$ in operational efficiency; $\triangle \mathrm{FP}=$ Change in future firm performance; $\Delta \mathrm{CCC}=$ Change in cash conversion cycle; $\Delta \mathrm{OE} \_\mathrm{SR}=$ Change in operating expenses to sales revenue ratio; $\Delta \mathrm{OCF}=$ Change in operating cash flow; $\Delta \mathrm{TAT}=$ Change in total asset turnover; $\Delta \mathrm{TDTA}=\mathrm{Change}$ in total debt to total assets ratio; $\Delta \mathrm{FS}=$ Change in firm size; $\Delta \mathrm{SD}=$ Change in standard deviation (operating risk).

\subsection{Pearson Bivariate Correlation Analysis}

The Pearson Bivariate Correlation Analysis showed that:

i) Future firm performance (measured by changes in share price, $\Delta \mathrm{FP}_{10}$ ) is negatively correlated with changes in the cash conversion cycle and operating expenses to sales revenue ratios, and positively correlated with changes in operating cash flow and total debt to total assets ratios,

ii) $\Delta \mathrm{FP}_{11}$ is negatively correlated with changes in the cash conversion cycle and standard deviation (operating risk), and positively correlated with changes in operating cash flow, and

iii) $\triangle \mathrm{FP}_{12}$ is negatively correlated with changes in the cash conversion cycle and standard deviation (operating risk), and positively correlated with changes in operating expenses to sales revenue, operating cash flow, and total asset turnover ratios (See Table 4). 
Table 4. Pearson bivariate correlation analysis

\begin{tabular}{|c|c|c|c|c|c|c|c|c|}
\hline \multicolumn{9}{|c|}{$\Delta \mathrm{OE}$ From 2008 to 2009 and $\Delta \mathrm{FP}$ From 2009 to $2010\left(\Delta \mathrm{FP}_{10}\right)$} \\
\hline & $\Delta \mathrm{FP}_{10}$ & $\Delta \mathrm{CCC}_{09}$ & $\Delta \mathrm{OE} \_\mathrm{SR}_{09}$ & $\triangle \mathrm{OCF}_{09}$ & $\Delta \mathrm{TAT}_{09}$ & $\Delta \mathrm{TDTA}_{09}$ & $\Delta \mathrm{FS}_{09}$ & $\Delta \mathrm{SD}_{09}$ \\
\hline$\Delta \mathrm{FP}_{10}$ & 1 & $-0.235 * * *$ & $-0.250 * * *$ & $0.252 * * *$ & 0.107 & $0.155^{* *}$ & -0.120 & -0.129 \\
\hline$\Delta \mathrm{CCC}_{09}$ & & 1 & 0.005 & $-0.137 * *$ & -0.093 & $-0.223 * * *$ & 0.078 & -0.011 \\
\hline$\Delta \mathrm{OE} \_\mathrm{SR}_{09}$ & & & 1 & -0.095 & $-0.184 * * *$ & 0.055 & 0.064 & -0.127 \\
\hline$\Delta \mathrm{OCF}_{09}$ & & & & 1 & 0.029 & 0.023 & -0.118 & -0.031 \\
\hline$\Delta \mathrm{TAT}_{09}$ & & & & & 1 & -0.084 & $-0.363 * * *$ & 0.060 \\
\hline$\Delta \mathrm{TDTA}_{09}$ & & & & & & 1 & $0.211^{* * *}$ & -0.071 \\
\hline$\Delta \mathrm{FS}_{09}$ & & & & & & & 1 & 0.059 \\
\hline$\Delta \mathrm{SD}_{09}$ & & & & & & & & 1 \\
\hline \multicolumn{9}{|c|}{$\Delta \mathrm{OE}$ From 2009 to 2010 and $\Delta \mathrm{FP}$ From 2010 to $2011\left(\Delta \mathrm{FP}_{11}\right)$} \\
\hline & $\Delta \mathrm{FP}_{11}$ & $\Delta \mathrm{CCC}_{10}$ & $\Delta \mathrm{OE} \_\mathrm{SR}_{10}$ & $\Delta \mathrm{OCF}_{10}$ & $\Delta \mathrm{TAT}_{10}$ & $\Delta$ TDTA $_{10}$ & $\Delta \mathrm{FS}_{10}$ & $\Delta \mathrm{SD}_{10}$ \\
\hline$\Delta \mathrm{FP}_{11}$ & 1 & $-0.183 * * *$ & -0.045 & $0.243 * * *$ & -0.029 & -0.053 & -0.080 & $-0.168 * *$ \\
\hline$\Delta \mathrm{CCC}_{10}$ & & 1 & .079 & -0.075 & -0.040 & 0.095 & -0.010 & 0.099 \\
\hline$\Delta \mathrm{OE} \_\mathrm{SR}_{10}$ & & & 1 & -0.113 & $-0.210 * * *$ & $0.144 * *$ & $0.241 * * *$ & 0.065 \\
\hline$\Delta \mathrm{OCF}_{10}$ & & & & 1 & -0.090 & $-0.127 * *$ & -0.115 & -0.095 \\
\hline$\Delta \mathrm{TAT}_{10}$ & & & & & 1 & -0.053 & $-0.425 * * *$ & 0.017 \\
\hline$\Delta \mathrm{TDTA}_{10}$ & & & & & & 1 & $0.324 * * *$ & -0.008 \\
\hline$\Delta \mathrm{FS}_{10}$ & & & & & & & 1 & -0.039 \\
\hline$\Delta \mathrm{SD}_{10}$ & & & & & & & & 1 \\
\hline \multicolumn{9}{|c|}{$\Delta$ OE From 2010 to 2011 and $\Delta$ FP From 2011 to $2012\left(\Delta \mathrm{FP}_{12}\right)$} \\
\hline & $\Delta \mathrm{SP}_{12}$ & $\Delta \mathrm{CCC}_{11}$ & $\Delta \mathrm{OE} \_\mathrm{SR}_{11}$ & $\Delta \mathrm{OCF}_{11}$ & $\Delta \mathrm{TAT}_{11}$ & $\Delta \mathrm{TDTA}_{11}$ & $\Delta \mathrm{FS}_{11}$ & $\Delta \mathrm{SD}_{11}$ \\
\hline$\Delta \mathrm{SP}_{12}$ & 1 & $-0.165^{* * *}$ & $0.150^{* *}$ & $0.206^{* * *}$ & $0.198 * * *$ & 0.081 & -0.088 & $-0.214^{* * *}$ \\
\hline$\Delta \mathrm{CCC}_{11}$ & & 1 & -0.076 & -0.109 & $-0.224 * * *$ & 0.043 & -0.057 & 0.083 \\
\hline$\Delta \mathrm{OE} \_\mathrm{SR}_{11}$ & & & 1 & 0.115 & -0.059 & -0.069 & 0.098 & -0.034 \\
\hline$\Delta \mathrm{OCF}_{11}$ & & & & 1 & -0.002 & -0.073 & 0.082 & $-0.207 * * *$ \\
\hline$\Delta \mathrm{TAT}_{11}$ & & & & & 1 & -0.092 & $-0.396 * * *$ & $-0.167^{* * *}$ \\
\hline$\Delta \mathrm{TDTA}_{11}$ & & & & & & 1 & 0.032 & 0.028 \\
\hline$\Delta \mathrm{FS}_{11}$ & & & & & & & 1 & 0.000 \\
\hline$\Delta \mathrm{SD}_{11}$ & & & & & & & & 1 \\
\hline
\end{tabular}

\section{Analysis and Findings}

In this section, we present the empirical findings concerning the relationship between changes in operational efficiency and changes in future performance of Indian manufacturing firms.

The weighted least square model with cross section weight of two industries (consumer products manufacturing and industrial products manufacturing) was used to correct for the problem of heteroskedasticity (changing variation after a short period of time). In the regression, the common intercept was calculated for all variables and assigned a weight.

There was the possibility of endogeneity issues because of the use of multiple regression analysis. The issues of endogeneity also occur if certain variables are omitted and there are measurement errors (Gill \& Biger, 2013). To minimize endogeneity issues, the most important variables that impact future performance of the firm were used; the measurements were borrowed from previous empirical studies.

\subsection{Operational Efficiency and Future Firm Performance}

The results provided in Table 5 show that:

i) Change in future firm performance (measured by changes in share price, $\Delta \mathrm{FP}_{10}$ ) is negatively associated with $\Delta \mathrm{CCC}_{09}$. When control variables are included in the Weighted Least Square (WLS) regression analysis, $\Delta \mathrm{FP}_{10}$ is positively associated with $\Delta \mathrm{TDTA}_{09}$, and negatively associated with $\Delta \mathrm{FS}_{09}$ and $\Delta \mathrm{SD}_{09}$.

ii) $\Delta \mathrm{FP}_{10}$ is negatively associated with $\triangle \mathrm{OE} \_\mathrm{SR}_{09}$. When control variables are included in the WLS regression analysis, $\Delta \mathrm{FP}_{10}$ is positively associated with $\Delta \mathrm{TDTA}_{09}$, and negatively associated with $\Delta \mathrm{FS}_{09}$ and $\Delta \mathrm{SD}_{09}$.

iii) $\triangle \mathrm{FP}_{10}$ is positively associated with $\Delta \mathrm{OCF}_{09}$. When control variables are included in the WLS regression 
analysis, $\Delta \mathrm{FP}_{10}$ is positively associated with $\Delta \mathrm{TDTA}_{09}$, and negatively associated with $\Delta \mathrm{FS}_{09}$ and $\Delta \mathrm{SD}_{09}$.

iv) $\Delta \mathrm{FP}_{10}$ is not the function of $\triangle \mathrm{TAT}_{09}$. When control variables are included in the WLS regression analysis, $\Delta \mathrm{FP}_{10}$ is positively associated with $\Delta \mathrm{TDTA}_{09}$, and negatively associated with $\Delta \mathrm{FS}_{09}$ and $\Delta \mathrm{SD}_{09}$.

Note that a test for multicollinearity was performed. All of the variance inflation factor (VIF) coefficients are less than 2 and tolerance coefficients are greater than 0.50 .

Table 5. WLS regression estimates on factors affecting future firm performance

\begin{tabular}{|c|c|c|c|c|c|c|c|c|}
\hline & \multicolumn{8}{|c|}{ Dependent variable $=\Delta \mathrm{FP}_{10}$} \\
\hline & 1 & 2 & 3 & 4 & 5 & 6 & 7 & 8 \\
\hline \multirow[t]{2}{*}{$\Delta \mathrm{CCC}_{09}$} & $-0.04 * *$ & $-0.03 *$ & & & & & & \\
\hline & $(-3.17)$ & $(-2.79)$ & & & & & & \\
\hline \multirow[t]{2}{*}{$\Delta \mathrm{OE} \_\mathrm{SR}_{09}$} & & & $-0.44 * * *$ & $-0.47 * * *$ & & & & \\
\hline & & & $(-3.58)$ & $(-3.87)$ & & & & \\
\hline \multirow[t]{2}{*}{$\Delta \mathrm{OCF}_{09}$} & & & & & $0.05 * * *$ & $0.05 * * *$ & & \\
\hline & & & & & $(3.81)$ & $(3.85)$ & & \\
\hline \multirow[t]{2}{*}{$\Delta \mathrm{TAT}_{09}$} & & & & & & & 0.13 & 0.11 \\
\hline & & & & & & & $(1.63)$ & $(1.30)$ \\
\hline \multirow[t]{2}{*}{$\Delta \mathrm{TDTA}_{09}$} & & $0.15^{*}$ & & $0.20 * *$ & & $0.19 * *$ & & $0.20 * *$ \\
\hline & & $(1.81)$ & & $(2.46)$ & & $(2.32)$ & & $(2.36)$ \\
\hline \multirow[t]{2}{*}{$\Delta \mathrm{FS}_{09}$} & & $-2.35 * *$ & & $-2.32 * *$ & & $-2.74 *$ & & $-2.18 * *$ \\
\hline & & $(-2.27)$ & & $(-2.28)$ & & $(-2.70)$ & & $(-1.98)$ \\
\hline \multirow[t]{2}{*}{$\Delta \mathrm{SD}_{09}$} & & $-0.01 * *$ & & $-0.01 * *$ & & $-0.01 * *$ & & $-0.01 * *$ \\
\hline & & $(-2.04)$ & & $(-2.42)$ & & $(-1.79)$ & & $(-2.00)$ \\
\hline \multirow[t]{2}{*}{ Constant } & $-0.45^{* * *}$ & $-0.41 * * *$ & $-0.44 * * *$ & $-0.40 * * *$ & $-0.46 * * *$ & $-0.42 * * *$ & $-0.46^{* * *}$ & $-0.46^{* * *}$ \\
\hline & $(-22.34)$ & $(-12.75)$ & $(-20.46)$ & $(-12.22)$ & -22.96 & $(-13.31)$ & $(-22.56)$ & $(-22.56)$ \\
\hline Obs & 244 & 244 & 244 & 244 & 244 & 244 & 244 & 244 \\
\hline F-test & $10.03 * *$ & $5.65 * * *$ & $12.83 * * *$ & $7.56^{* * *}$ & $14.49 * * *$ & $7.52 * * *$ & 2.70 & $4.02 * *$ \\
\hline $\mathrm{R}^{2}$ & 0.04 & 0.09 & 0.05 & 0.12 & 0.06 & 0.12 & 0.01 & 0.07 \\
\hline $\operatorname{Adj} R^{2}$ & 0.04 & 0.08 & 0.05 & 0.10 & 0.06 & 0.10 & 0.01 & 0.05 \\
\hline
\end{tabular}

Note. ${ }^{*} \mathrm{p}<0.10,{ }^{* *} \mathrm{p}<0.05$, and $* * * \mathrm{p}<0.01$.

The results provided in Table 6 show that:

i) $\triangle \mathrm{FP}_{11}$ is negatively associated with $\triangle \mathrm{CCC}_{10}$. When control variables are included in the WLS regression analysis, $\Delta \mathrm{FP}_{11}$ is negatively associated with $\Delta \mathrm{TDTA}_{10}$ and $\Delta \mathrm{SD}_{10}$.

ii) $\Delta \mathrm{FP}_{11}$ is not the function of $\Delta \mathrm{OE} \_\mathrm{SR}_{10}$. When control variables are included in the WLS regression analysis, $\Delta \mathrm{FP}_{11}$ is negatively associated with $\Delta \mathrm{SD}_{10}$.

iii) $\triangle \mathrm{FP}_{11}$ is positively associated with $\Delta \mathrm{OCF}_{10}$. When control variables are included in the WLS regression analysis, $\Delta \mathrm{FP}_{11}$ is negatively associated with $\Delta \mathrm{SD}_{10}$.

iv) $\Delta \mathrm{FP}_{11}$ is not the function of $\Delta \mathrm{TAT}_{10}$. When control variables are included in the WLS regression analysis, $\Delta \mathrm{FP}_{11}$ is negatively associated with $\Delta \mathrm{SD}_{10}$.

Note that a test for multicollinearity was performed. All of the VIF coefficients are less than 2 and tolerance coefficients are greater than 0.50 .

Table 6. WLS regression estimates on factors affecting future firm performance

\begin{tabular}{|c|c|c|c|c|c|c|c|c|}
\hline & \multicolumn{8}{|c|}{ Dependent variable $=\Delta \mathrm{FP}_{11}$} \\
\hline & 1 & 2 & 3 & 4 & 5 & 6 & 7 & 8 \\
\hline$\Delta \mathrm{CCC}_{10}$ & $-0.06^{* *}$ & $-0.05 * *$ & & & & & & \\
\hline \multirow[t]{2}{*}{$\Delta \mathrm{OE} \_\mathrm{SR}_{10}$} & & & -0.14 & -0.04 & & & & \\
\hline & & & $(-0.62)$ & $(-0.16)$ & & & & \\
\hline
\end{tabular}




\begin{tabular}{|c|c|c|c|c|c|c|c|c|}
\hline & & & & & $(4.54)$ & $(4.22)$ & & \\
\hline$\Delta \mathrm{TAT}_{10}$ & & & & & & & $\begin{array}{l}-0.05 \\
(-0.34)\end{array}$ & $\begin{array}{l}-0.16 \\
(1.00)\end{array}$ \\
\hline$\Delta \mathrm{TDTA}_{10}$ & & $\begin{array}{l}-0.05^{*} \\
(-0.30)\end{array}$ & & $\begin{array}{l}-0.10 \\
(-0.64)\end{array}$ & & $\begin{array}{l}-003 \\
(-0.22)\end{array}$ & & $\begin{array}{l}-0.10 \\
(-0.64)\end{array}$ \\
\hline$\Delta \mathrm{FS}_{10}$ & & $\begin{array}{l}-1.66 \\
(-1.08)\end{array}$ & & $\begin{array}{l}-1.35 \\
(-0.86)\end{array}$ & & $\begin{array}{l}-1.16 \\
(-0.78)\end{array}$ & & $\begin{array}{l}-2.03 \\
(-1.21)\end{array}$ \\
\hline$\Delta \mathrm{SD}_{10}$ & & $\begin{array}{l}-0.02 * * \\
(-2.24)\end{array}$ & & $\begin{array}{l}-0.02 * * \\
(-2.43)\end{array}$ & & $\begin{array}{l}-0.02 * * \\
(-2.12)\end{array}$ & & $\begin{array}{l}-0.02 * * \\
(-2.50)\end{array}$ \\
\hline Constant & $\begin{array}{l}-0.04 \\
(-1.37)\end{array}$ & $\begin{array}{l}0.03 \\
(0.77)\end{array}$ & $\begin{array}{l}-0.04 \\
(-1.47)\end{array}$ & $\begin{array}{l}0.03 \\
(0.66)\end{array}$ & $\begin{array}{l}-0.05^{*} \\
(-1.84)\end{array}$ & $\begin{array}{l}0.01 \\
(0.27)\end{array}$ & $\begin{array}{l}-0.04 \\
(-1.39)\end{array}$ & $\begin{array}{l}0.04 \\
(0.86)\end{array}$ \\
\hline Obs & 244 & 244 & 244 & 244 & 244 & 244 & 244 & 244 \\
\hline F-test & $6.45^{* *}$ & $3.17 * *$ & 0.38 & 1.92 & $20.59 * * *$ & $6.52 * * *$ & 0.12 & $2.17 *$ \\
\hline $\mathrm{R}^{2}$ & 0.03 & 0.05 & 0.01 & 0.03 & 0.08 & 0.10 & 0.01 & 0.04 \\
\hline Adj $R^{2}$ & 0.02 & 0.04 & -0.01 & 0.02 & 0.08 & 0.09 & -0.01 & 0.02 \\
\hline
\end{tabular}

The results provided in Table 7 show that:

i) $\triangle \mathrm{FP}_{12}$ is negatively associated with $\triangle \mathrm{CCC}_{11}$. When control variables are included in the WLS regression analysis, $\Delta \mathrm{FP}_{12}$ is negatively associated with $\Delta \mathrm{SD}_{11}$.

ii) $\triangle \mathrm{FP}_{12}$ is positively associated with $\triangle \mathrm{OE} \_\mathrm{SR}_{11}$. When control variables are included in the WLS regression analysis, $\Delta \mathrm{FP}_{12}$ is negatively associated with $\Delta \mathrm{SD}_{11}$.

iii) $\triangle \mathrm{FP}_{12}$ is positively associated with $\triangle \mathrm{OCF}_{11}$. When control variables are included in the WLS regression analysis, $\Delta \mathrm{FP}_{12}$ is negatively associated with $\Delta \mathrm{SD}_{11}$.

iv) $\Delta \mathrm{FP}_{12}$ is positively associated with $\triangle \mathrm{TAT}_{11}$. When control variables are included in the WLS regression analysis, $\Delta \mathrm{FP}_{12}$ is negatively associated with $\Delta \mathrm{SD}_{11}$.

Note that a test for multicollinearity was performed. All of the variance inflation factor (VIF) coefficients are less than 2 and tolerance coefficients are greater than 0.50 .

Table 7. WLS regression estimates on factors affecting future firm performance

\begin{tabular}{|c|c|c|c|c|c|c|c|c|}
\hline & \multicolumn{8}{|c|}{ Dependent variable $=\Delta \mathrm{FP}_{12}$} \\
\hline & 1 & 2 & 3 & 4 & 5 & 6 & 7 & 8 \\
\hline \multirow[t]{2}{*}{$\Delta \mathrm{CCC}_{11}$} & $-0.06^{* *}$ & $-0.05 * * *$ & & & & & & \\
\hline & $(-2.95)$ & $(-2.86)$ & & & & & & \\
\hline \multirow[t]{2}{*}{$\Delta \mathrm{OE} \_\mathrm{SR}_{11}$} & & & $0.41 * *$ & $0.43 * * *$ & & & & \\
\hline & & & $(-2.50)$ & $(2.68)$ & & & & \\
\hline \multirow[t]{2}{*}{$\Delta \mathrm{OCF}_{11}$} & & & & & $0.04 * * *$ & $0.04 * * *$ & & \\
\hline & & & & & $(3.07)$ & $(2.78)$ & & \\
\hline \multirow[t]{2}{*}{$\Delta \mathrm{TAT}_{11}$} & & & & & & & $0.26^{* * *}$ & $0.23^{* *}$ \\
\hline & & & & & & & $(2.93)$ & $(2.39)$ \\
\hline \multirow[t]{2}{*}{$\Delta \mathrm{TDTA}_{11}$} & & 0.16 & & 0.18 & & 0.19 & & 0.17 \\
\hline & & $(1.33)$ & & $(1.50)$ & & $(1.52)$ & & $(1.40)$ \\
\hline \multirow[t]{2}{*}{$\Delta \mathrm{FS}_{11}$} & & -1.23 & & -1.48 & & -1.43 & & -0.18 \\
\hline & & $(-1.78)$ & & $(-1.41)$ & & $(-1.36)$ & & $(-0.87)$ \\
\hline \multirow[t]{2}{*}{$\Delta \mathrm{SD}_{11}$} & & $-0.02 * * *$ & & $-0.02 * * *$ & & $-0.02 * *$ & & $-0.02 * *$ \\
\hline & & $(-2.88)$ & & $(-2.97)$ & & $(-2.45)$ & & $(-2.60)$ \\
\hline \multirow[t]{2}{*}{ Constant } & $-0.11 * * *$ & -0.04 & $-0.12 * * *$ & $-0.06^{*}$ & $-0.10 * * *$ & -0.04 & $-0.10 * * *$ & $-0.07^{*}$ \\
\hline & $(-4.59)$ & $(-1.28)$ & $(-5.18)$ & $(-1.66)$ & -4.14 & $(-1.08)$ & $(-4.66)$ & $(-1.94)$ \\
\hline Obs & 244 & 244 & 244 & 244 & 244 & 244 & 244 & 244 \\
\hline F-test & $8.70 * * *$ & $5.05 * * *$ & $6.23 * *$ & $4.78 * * *$ & $9.40 * * *$ & $4.92 * * *$ & $8.60 * * *$ & $4.39 * * *$ \\
\hline $\mathrm{R}^{2}$ & 0.04 & 0.08 & 0.03 & 0.07 & 0.04 & 0.08 & 0.03 & 0.07 \\
\hline $\operatorname{Adj} R^{2}$ & 0.03 & 0.06 & 0.02 & 0.06 & 0.03 & 0.06 & 0.03 & 0.05 \\
\hline
\end{tabular}

Note. ${ }^{*} \mathrm{p}<0.10,{ }^{* *} \mathrm{p}<0.05$, and ${ }^{* * *} \mathrm{p}<0.01$. 


\subsection{Random and Fixed-Effects}

The random and fixed effects of the independent variables on the dependent variables indicate that the impact of operational efficiency on future performance of Indian manufacturing firms differs from sector to sector and from year to year.

\section{Discussion}

The main purpose of this study was to determine the impact of changes in operational efficiency on the future performance of the Indian manufacturing firms. The findings related to the relationship between cash conversion cycle and future performance show that long cash conversion cycle negatively impacts on the future performance of the firm. While the total debt to total assets ratio positively impacts the future performance of the firm, higher level of operating risk negatively impacts on the future performance of the firm. Thus, hypothesis 1 which indicates that the changes in cash conversion cycle impact the future performance of the firm is supported.

The results related to the relationship between operating expenses to sales revenue negatively impacts the future performance of the firm. While the total debt to total assets ratio positively impacts the future performance of the firm, higher level of operating risk negatively impacts on the future performance of the firm. Thus, hypothesis 2 which indicates that the changes in operating expenses impact the future performance of the firm is supported.

The findings related to the relationship between operating cash flow and future performance shows that operating cash flow positively impacts the future performance of the firm. While the total debt to total assets ratio positively impacts the future performance of the firm, higher level of operating risk negatively impacts on the future performance of the firm. Thus, hypothesis 3 which indicates that the changes in operating cash flow impact the future performance of the firm is supported.

Although, the results related the relationship between total asset turnover and the future performance of the firm shows positive impact of total asset turnover on the future performance, they are not consistent. However, the relationship between the level of risk and future firm performance are consistent; that is, higher the level of operating risk, the lower the level of future firm performance. Thus, hypothesis 4 which indicates that the changes in asset turnover impact the future performance of the firm is partially supported.

The above findings show that an increase in the cash conversion cycle, operating risk, and operating expenses negatively impact the future performance of the firm. The total asset turnover and operating cash flow, however, positively impact future performance, which is because total asset turnover and operating cash flow play a role in improving corporate solvency. The findings also show that variables that cause changes in future firm performance differ from year to year and sector to sector. Therefore, financial analysts should use ratios with caution at the time of financial analysis. The exogenous shocks such as shortage of raw materials because of bad weather, changes in the economic condition of India, etc., may be some of the factors that cause changes. There are also other internal factors such as wastage of raw material, unskilled labor, etc., that should not be ignored because they cause changes in future firm performance quickly.

The findings of this study lend some support to the findings of Ou and Penman (1989), Raheman and Nasr (2007), Falope and Ajilore (2009), Baik, Chae, Choi, and Farber (2010), Ahmad and Noor (2010), Dietrich (2010), and Rahman and Farah (2012).

\section{Conclusion, Recommendations, Practical Implications, and the Signs of Operational Efficiency Improvement}

The results of the present study show that changes in operational efficiency cause changes in future performance of Indian manufacturing firms. Findings also show that an increase in the cash conversion cycle has a negative impact on the future performance of the firm.

A positive change in the total debt to total assets ratio improves the future performance of the Indian manufacturing firms. A reduction in total asset turnover positively impacts the future performance of the firm (see Table 5). This finding indicates that the Indian manufacturing industry has high profit margin which lead to low asset turnover. However, this finding is not consistent. Therefore, finding should be used with caution.

Since an increase in the cash conversion cycle negatively impacts the future performance of Indian manufacturing firms, managers can create positive value for the shareholders by reducing the cash conversion cycle to a minimum level. To reduce cash conversion cycle, Indian manufacturing firms may consider:

- Reducing $\mathrm{A} / \mathrm{R}$ period by offering cash discounts to speed up A/R collection.

- Following up on overdue $\mathrm{A} / \mathrm{R}$ accounts on a regular basis. 
- Accepting electronic money (i.e., transfer of funds for A/R electronically).

- Using five Cs of credit (i.e., character, capacity, collateral, conditions, and capital) before approving credit limits.

- Using lockboxes to speed up A/R collections.

- Reducing inventory period by increasing inventory turnover and by using inventory control methods and models, such as economic order quantity (EOQ) and just-in-time (JIT).

All of the above recommendations may help Indian manufacturing firms in improving cash flow from operating activities that have a positive impact on the future performance of the firm. The above recommendations may also help Indian manufacturing firms in reducing operating risk by reducing the variance in operating cash flows. However, one should not forget about the practical implications of the study. The practical implication of this study is that the recommendations may not be applied on every Indian manufacturing firm because:

- Of the different situations (e.g., market competition in different geographic locations) that each manufacturing firm faces.

- Board of directors may not support changes in A/R and inventory management policies.

- Financial managers may not be able to implement changes in $\mathrm{A} / \mathrm{R}$ and inventory management policies due to reluctance from different departments such as marketing, finance, production, etc.

Based on the practical implications, the implementation of changes requires board of directors and senior financial managers to internalize the importance of showing genuine concern and respect for managers from other departments.

As findings suggest that $\mathrm{OE}$ impacts the future performance of the firm, it is important for the Indian manufacturing firms to understand the signs of OE improvement. The signs of OE improvement are:

- Reduction in operating costs without damaging the corporation.

- Reduction in CCC period.

- Improvement in OCF.

- Increase in the total asset turnover (particularly in inventory turnover).

- Reduction in operating risk (i.e., reduction in standard deviation of OCF).

\section{Limitations}

This is a correlational study that investigated the association between the changes in operating efficiency and changes in future firm performance. There is not necessarily a causal relationship between the two, although some conjectures were provided in relation to the findings.

This study is limited to the sample of Indian manufacturing firms. The national scope of the sample may also affect the conclusions of the paper and the sample we took may be biased because of the fact that only publically traded companies were included in the data set.

The findings of this study could only be generalized to firms similar to those that were included in this research. In addition, the sample size is small.

\section{Future Research}

Future research should investigate generalizations of the findings beyond the Indian firms. Important control variables such as industry sectors from different countries should also be used.

\section{References}

Abarbanell, J. S., \& Bernard, V. L. (1992). Tests of analysts' overreaction/under-reaction to earnings information as an explanation for anomalous stock price behavior. Journal of Finance, 47, 1181-1207. http://dx.doi.org/10.1111/j.1540-6261.1992.tb04010.x

Abuzayed, B., \& Molyneux, P. (2009). Market value, book value and earnings: Is bank efficiency a missing link? Managerial Finance, 35(2), 156-179. http://dx.doi.org/10.1108/03074350910923491

Ahmad, N. H., \& Noor, M. K. (2010). The determinants efficiency and profitability of world Islamic banks. 2010 International Conference on E-business, Management and Economics, 3, 228-233. Retrieved from http://www.ipedr.com/vol3/47-M10013.pdf

Baik, B., Chae, J., Choi, S., \& Farber, D. B. (2010). Changes in operational efficiency and firm performance: A 
frontier analysis approach. Retrieved from http://eprints.lancs.ac.uk/61599/1/care1179.pdf

Dietrich, M. (2010). Efficiency and profitability: A panel data analysis of UK manufacturing firms, 1993-2007. Sheffield Economic Research Paper Series, 1-45. Retrieved from http://eprints.whiterose.ac.uk/10270/1/SERPS2010003.pdf

Fairfield, P. M., \& Yohn, T. L. (2001). Using asset turnover and profit margin to forecast changes in profitability. Review of Accounting Studies, 6(4), 371-385. http://dx.doi.org/10.1023/A:1012430513430

Falope, O. I., \& Ajilore, O. T. (2009). Working capital management and corporate profitability: Evidence from panel data analysis of selected quoted companies in Nigeria. Research Journal of Business Management, 3(3), 73-84. http://dx.doi.org/10.3923/rjbm.2009.73.84

Gill, A,. \& Biger, N. (2013). The impact of corporate governance on working capital management efficiency of American manufacturing firms. Managerial Finance, 39(2), 116-132. http://dx.doi.org/10.1108/03074351311293981

Gill, A., Biger, N., \& Tibrewala, R. (2010). Determinants of dividend payout ratios: Evidence from United States. The Open Business Journal, 3, 8-14. http://dx.doi.org/10.2174/1874915101003010008

Homsud, N., \& Choksuchat, R. (2012). The operation efficiency evaluation by financial ratio of listed company in food and beverage industry by grey principal component analysis. European Journal of Economics, Finance and Administrative Sciences, 45, 148-152. Retrieved from http://www.europeanjournalofeconomicsfinanceandadministrativesciences.com

Hossan, F., \& Habib, M. A. (2010). Performance evaluation and ratio analysis of Pharmaceutical Company in Bangladesh. Master's thesis in international Business 15 ECTS, Department of Economic and Informatics, University West.

Lev, B., \& Thiagarajan, S. R. (1993). Fundamental information analysis. Journal of Accounting Research, 31, 190-215. http://dx.doi.org/10.2307/2491270

Lipe, R. (1986). The information contained in the components of earnings. Journal of Accounting Research, 24 , 37-68. http://dx.doi.org/10.2307/2490728

McWilliams, A., \& Smart, D. (1993). Efficiency vs. structure-conduct-performance: Implications for strategy research and practice. Journal of Management, 19, 63-78. http://dx.doi.org/10.1177/014920639301900105

Nissim, D., \& Penman, S. (2001). Ratio analysis and equity valuation: From research to practice. Review of Accounting Studies, 6, 109-154. http://dx.doi.org/10.1023/A:1011338221623

Ohlson, J., \& Penman, S. (1992). Disaggregated accounting data as explanatory variables for returns. Journal of Accounting, Auditing and Finance, 7, 553-573.

Ou, J. A., \& Penman, S. H. (1989). Financial statement analysis and the prediction of stock returns. Journal of Accounting and Economics, 11(4), 295-329. http://dx.doi.org/10.1016/0165-4101(89)90017-7

Penman S., \& Zhang, X. (2002). Accounting conservatism, the quality of earnings and stock returns. The Accounting Review, 77, 237-264. http://dx.doi.org/10.2308/accr.2002.77.2.237

Raheman, A., \& Nasr, M. (2007). Working capital management and profitability-Case of Pakistani firms. International Review of Business Research Papers, 3(1), 279-300.

Rahman, S., \& Farah, T. (2012). Non-bank financial institutions' profitability indicators: Evidence from Bangladesh. International Journal of Applied Research in Business Administration and Economics, 1(1), 26-32. Retrieved from http://www.setscholars.org/index.php/ijarbae/article/download/85/101

Sharma, S., \& Singh, B. (2006). Determinants of equity share prices in Indian corporate sector: An empirical study. The ICFAI Journal of Applied Finance, 12(4), 21-38. Retrieved from http://www.iupindia.in/applied_finance.asp

\section{Copyrights}

Copyright for this article is retained by the author(s), with first publication rights granted to the journal.

This is an open-access article distributed under the terms and conditions of the Creative Commons Attribution license (http://creativecommons.org/licenses/by/3.0/). 